\title{
Assessment of the Quality of the Training System in Moroccan Higher Education Institutions: Case of the Sciences and Technics of Physical and Sports Activities
}

\author{
Mohamed ESSAOUDI ${ }^{1}$ and Raja LOTFI ${ }^{2}$ \\ ${ }^{1}$ Management and Governance Department, Inspectors Training Center for Teaching (CFIE) - Rabat, Morocco. \\ ${ }^{2}$ Department: Management Techniques, Laboratory for Research on Organizational Management (LAREMO), \\ Higher School of Technology (EST), Hassan II University, 20020 - Casablanca, Morocco.
}

\begin{abstract}
:
Purpose. The aim of our study is to assess the overall quality of the university training system (UTS) in sciences and techniques of physical and sports activities (STPSA) in Moroccan higher education.

Method. Our method was based on a quantitative, exploratory and correlational approach. The independent variable (the quality of services provided by the UTS in STPSA) and the dependent variable (overall student satisfaction) were investigated empirically and statistically. 256 students from five STPSA institutions of higher education were surveyed. Two measurement tools were used: an adapted version of the SERVQUAL instrument and a validated questionnaire of satisfaction with the TS -STPSA domains. The internal consistency of the two measurement instruments was tested and confirmed. Similarly, the inter-dimensional correlation matrix was examined to verify the statistical reliability of our scales and their appropriateness to the STPSA context.

Results. The overall quality of training services was perceived by $59 \%$ of students as unsatisfactory. Empathy is the strongest determinant of TS quality in STPSA. While responsiveness is the weakest dimension. The two dimensions of "Reliability" and "Assurance" reinforce students' dissatisfaction with the STPSA major with negative gaps of -1.42 and -1.37 respectively. While "Tangibility" is the most neutral dimension with almost no difference. These five dimensions explain $45.7 \%$ of the variation in overall student satisfaction. They have a positive effect on the satisfaction of students' STPSA. The correlation examination, between the dimensions of service quality and satisfaction with the STPSA-TS domains, revealed seven positively significant relationships, including three between students' "Overall Satisfaction" and the dimensions of "Tangibility", "Responsiveness" and "Empathy". Conclusion. Globally, the quality of TS in Moroccan STPSA is unsatisfactory and leaves much to be desired. The students' expectations greatly exceed their perception of the effective quality of the TS. This suggests that STPSA fields are not effectively fulfilling the students' initial expectations. This judgment is characterized by "negative" quality gaps in three of the five dimensions of the SERVQUAL scale (Responsiveness, Reliability and Assurance). The produced outcomes remain referential to allow STPSA managers to improve the quality of their services. However, students' expectations and perceptions are subjective and rarely stable over time. They vary according to several variable factors (mood, emotion, stress, motivation...). A longitudinal study could be conducted later to overcome or mitigate these limitations.
\end{abstract}

Keywords: Perceived Quality - SERVQUAL - University Training System - Student satisfaction - STPSA courses - Higher education.

\section{INTRODUCTION}

The education quality and training has become an international watchword. It's one of the main goals championed by both UNESCO, in its last two reports (on accountability in education [1] and on inclusion in education [2]), and the World Bank, which aims to improve the systems quality education and develop students' skills [3]. Quality also remains a key reference for the OECD [4]. This conception of the education-training quality, put forward by the major international organizations, tends to become a regulatory obligation.

Beyond this observation, the quality of the training systems (TS) in the fields of sciences and techniques of physical and sports activities (STPSA) remains difficult to circumscribe or to evaluate. It seems to depend on contextual parameters (internal and external), on characteristics of the stakeholders involved and the technical and practical specificities of STPSA, in order to present an adapted and quality training offer. To question 
the evaluation of the quality of a TS in STPSA cannot be done without first raising the multidimensional and complex character of the concept of "quality in STPSA" and underlining the conceptual and methodological questions it raises. In general, there are two main approaches to managing and accessing the quality of university training systems: a standardization or referentialization approach, and a satisfaction measurement and evaluation approach.

The first approach is based on one or more existing benchmarks that most often outline the " quality model " adapted to the realities of the higher education context [5]; [6]. The quality of the DDF should be assessed solely on the basis of objective compliance with predefined standards and requirements (objective quality). Among these repositories, five main models stand out, namely the Quality Deming model, the Malcolm Baldrige National Academy model, the ISO 9000 standards, the European Foundation for Quality Management model and the European Quality Improvement System model. These various frameworks all agree that quality does not reside in a single characteristic, but in the combination of a coherent set of attributes appreciated by the customer, in this case the student (perceived quality) [7].

The second approach is based on customer satisfaction as a guiding and determining parameter of the quality of any TS. Organizations do not do "quality for quality's sake", but do it primarily to attract, satisfy and retain their customers on the one hand, and to compete with their rivals on the other. Customer satisfaction is the very foundation of quality. Indeed, the parameter of student satisfaction has become essential and strategically unavoidable [8]. It's an indicator of the services quality provided [9]. Thus, satisfaction is used for pedagogical purposes [10], university resource evaluation purposes [11], but also for managerial purposes [12].

Accordingly, our research would attempt to combine these two approaches into a quality assessment approach for STPSA- TS in five Moroccan regulated-access academic institutions. We believe that the determinants of the quality of a TS in STAPS lie in the student's perception of the various components of the " servuction " and in the satisfaction he/she gets from this service provision. Therefore, the aim of our study is to assess the global quality of the training system (TS) in sciences and techniques of physical and sports activities (STPSA) in Moroccan higher education.

\section{Methodology}

Our study favors a methodological approach that is both quantitative, exploratory, and correlational. The independent variable (the quality of services provided by the TS in STPSA) and the dependent variable (student overall satisfaction) were studied empirically and statistically.

\section{A. Sample}

The study sample is composed of 256 students from five higher education STPSA institutions (6 Bachelor's degrees and 3 Master's degrees). This is statistically very representative for this young field in the kingdom. Our sample was asked to answer two questionnaires respectively of 22 and 17 items ( 39 items in total). $59 \%$ of the respondents were male and $41 \%$ were female. 181 respondents were between 18 and 20 years old, and 75 were between 21 and 25 years old. $16 \%$ of respondents were first-year students, $41 \%$ were second-year, $38 \%$ were third year and $5 \%$ were master's students. We can observe that the distribution of our respondents in the second and third grades is roughly equal. Compared to the original target sample, we have a response rate of $87.97 \%$, which is considered very acceptable.

TABLE I. CHARACTERISTICS OF THE STUDY SAMPLE.

\begin{tabular}{|c|c|c|}
\hline $\begin{array}{c}\text { University } \\
\text { Establishments }\end{array}$ & $\begin{array}{c}\text { Bachelor's degrees } \\
\text { in STPSA }\end{array}$ & $\begin{array}{c}\text { STPSA Masters } \\
\text { degree }\end{array}$ \\
\hline $\begin{array}{c}\text { Higher Normal School } \\
\text { (ENS) of Casablanca }\end{array}$ & $\begin{array}{c}\text { - Sport \& Leisure } \\
\text { - Physical Education } \\
\text { and Sport }\end{array}$ & - \\
\hline $\begin{array}{c}\text { Sport Sciences Institute } \\
\text { (ISS) of Settat }\end{array}$ & $\begin{array}{c}\text { - Sport Management } \\
\text { - Physical Education } \\
\text { and Sport }\end{array}$ & - \\
\hline $\begin{array}{c}\text { National Sports Center - } \\
\text { Royal institute for } \\
\text { management training } \\
\text { (CNS - IRFC) Moulay } \\
\text { Rachid -Sale }\end{array}$ & $\begin{array}{c}\text { - Sport management } \\
\text { management and } \\
\text { Optimizing High } \\
\text { Performance } \\
\text { - Sport }\end{array}$ \\
\hline $\begin{array}{c}\text { Higher Normal School } \\
\text { (ENS) of Fès }\end{array}$ & $\begin{array}{c}\text { Management and } \\
\text { Governance }\end{array}$ \\
\hline $\begin{array}{c}\text { Faculty of Educational } \\
\text { Sciences (FSE) of Rabat }\end{array}$ & and Sport & \\
\hline
\end{tabular}

\section{B. Measurement Instrument}

The study instruments consist of a SERVQUAL measurement scale and a satisfaction questionnaire, which respectively handle the concepts of "quality of services" and "student satisfaction".

\section{1) SERVQUAL Scale}

To measure the quality of services provided by the TS in STPSA, the required data were collected on the basis of an adapted version of the SERVQUAL instrument $[13,14]$. This instrument assesses five dimensions of service quality (tangibility, reliability, responsiveness, assurance and empathy), both in terms of the quality perceived (offered) and the quality expected.

Thus, following the findings of the two versions adopted respectively by [15] and [16], the items of our measurement instrument were adjusted to the context of STAPS in Moroccan higher education. We reformulated them after a pre-test with a sample of 51 STAPS students from the ENS 
of Casablanca. We preferred to reformulate them all in a positive way, contrary to [17] who wrote them in a positive or negative way. Our choice is justified by the need to keep the respondents' attention when reading the questions, since we noted during the pre-test that negative questions cause confusion, an additional effort of concentration among the respondents and an extension of the questionnaire administration time. Therefore, all our items are formulated positively, both in terms of expectations and perceived quality.

Our ServQual instrument includes two sections of 22 items each, measuring students' expectations (E) on the one hand and their perception $(\mathrm{P})$ of the quality of services received in training on the other. We used a 7-point Likerttype measurement scale, ranging from 1 (completely dissatisfied) to 7 (completely satisfied).

This allows us to calculate the differences in scores for each dimension, based on the gap theory [14], which suggests that the perception of service quality is a function of the difference between their expectations of the desired performance and their assessment of the performance actually produced [18].

\section{2) Satisfaction Questionnaire}

The STAPS student's satisfaction measurement allows us to evaluate the students' opinions and requirements, and to identify the causes of their dissatisfaction. The satisfaction measure reflects the students' attitude towards the TS services in STPSA. It's considered an indicator of service quality. Thus, this second questionnaire consists of 17 items divided into four areas: General satisfaction, Quality of training modules, Quality of training materials and Relevance of training methods.

The items and dimensions of this questionnaire were validated by four STPSA experts from higher education. A four-point Likert scale was used, ranging from not at all satisfied (1) to very satisfied (4). After counting and analyzing the data collected, 256 questionnaires (out of the 291 initially distributed) were retained and analyzed. Questionnaires with significant missing values or outliers were discarded.

\section{Data analysis methods}

For the data from the five dimensions of quality (ServQual instrument), we calculated the mean and standard deviation for both the perceived quality $(\mathrm{P})$ and the expected quality (E). Then, we examined their gap according to the formula $(\mathrm{P}-\mathrm{E}=\mathrm{Q})$. This equation represents the measure of service quality (Q). When $\mathrm{Q}$ is negative (i.e. $\mathrm{P}<\mathrm{E}$ ), then a service quality gap exists and leads to dissatisfaction. However, when Q is positive (i.e., $P>E$ ), then students' expectations are exceeded, resulting in high satisfaction. And when $\mathrm{P}=\mathrm{E}$, students' expectations coincide with their perceptions and result in normal satisfaction.

On the other hand, for the data from the four training domains (satisfaction questionnaire), we calculated the frequencies and percentages of each modality of the Likert scale.
Similarly, in order to evaluate the relationship between the scores of the four training domains and those of the five quality dimensions, we calculated correlation coefficients. We transformed the categorical modalities of the Likert scales into numerical data. Thus, the data are presented in a matrix, the significance of the coefficients is fixed by a probability of error $\mathrm{p}<0.05$.

Moreover, to check the reliability of the ServQual scale, we calculated Cronbach's Alpha $(\alpha)$ coefficient to assess its internal consistency and the bivariate Pearson correlation coefficient to assess the internal consistency between dimensions.

\section{FINDINGS}

In this section, we present the respective results of the assessment of the STPSA quality dimensions, the assessment of satisfaction with the TS domains, and those related to the correlative analysis between quality dimensions and STPSA training domains.

\section{A. The assessment of the TS-STPSA quality dimensions.}

First, we statistically test the reliability of the ServQual scale to confirm its psychometric properties, and then we present the results of the TS quality assessment.

1) Testing the reliability of the ServQual scale adapted to STAPS.

Internal consistency analysis of the scale shows that Cronbach's Alpha value $(\alpha)$ is sufficiently acceptable (alpha $=.758)$ (Table 2), as it exceeds the minimum required threshold of .70 [19,20].

Thus, all five dimensions (tangibility, reliability, responsiveness, assurance, and empathy) also indicate largely satisfactory values ranging from .7 relative to the "Assurance" variable to .83 for the "Responsiveness" dimension. The latter is considered the variable with the best internal consistency. Our measurement scale therefore has a sufficiently satisfactory internal consistency.

TABLE II. INTERNAL CONSISTENCY STATISTICS FOR THE DIMENSIONS OF THE ADAPTED SERVQUAL SCALE.

\begin{tabular}{|c|c|c|}
\hline Dimensions & $\begin{array}{c}\text { Cronbach's } \\
\text { Alpha ( } \boldsymbol{\alpha})\end{array}$ & $\begin{array}{c}\text { Number } \\
\text { of items }\end{array}$ \\
\hline Tangibility & 0.718 & 4 \\
\hline Reliability & 0.754 & 5 \\
\hline Responsiveness & 0.831 & 4 \\
\hline Assurance & 0.709 & 4 \\
\hline Empathy & 0.781 & 5 \\
\hline Total & 0.758 & 22 \\
\hline
\end{tabular}


The inter-dimensional correlation matrix (Table 3) shows that all dimensions are sufficiently correlated for us to consider that they measure the same construct.

The correlation coefficients are medium but significant, ranging from .325 to .594 . They therefore confirm the result presented in the previous table. Consequently, we can "serenely" exploit the ServQual adapted scale as a reliable tool for assessing the quality of STPSA training system.

TABLE III. CORRELATION MATRIX BETWEEN THE 5 DIMENSIONS OF SERVQUAL.

\begin{tabular}{|c|c|c|c|c|c|c|}
\hline \multicolumn{2}{|c|}{ Dimensions } & Tang. & Relia. & Resp. & Ass. & Emp. \\
\hline \multirow{2}{*}{ Tang. } & $\mathrm{r}$ & 1 & & & & \\
\hline & $\mathrm{p}$ & & & & & \\
\hline \multirow{2}{*}{ Relia. } & $\mathrm{r}$ & $.594^{* *}$ & 1 & & & \\
\cline { 2 - 8 } & $\mathrm{p}$ & .000 & & & & \\
\hline \multirow{2}{*}{ Resp. } & $\mathrm{r}$ & $.506^{* *}$ & $.556^{* *}$ & 1 & & \\
\cline { 2 - 8 } & $\mathrm{p}$ & .000 & .000 & & & \\
\hline \multirow{2}{*}{ Ass. } & $\mathrm{r}$ & $.350^{* *}$ & $.510^{* *}$ & $.325^{* *}$ & 1 & \\
\cline { 2 - 8 } & $\mathrm{p}$ & .000 & .000 & .000 & & \\
\hline \multirow{2}{*}{ Emp. } & $\mathrm{r}$ & $.480^{* *}$ & $.569^{* *}$ & $.482^{* *}$ & $.575^{* *}$ & 1 \\
\hline & $\mathrm{p}$ & .000 & .000 & .000 & .000 & \\
\hline
\end{tabular}

r: Pearson correlation coefficient, p: probability of significance. r: Correlation. ** Correlation is significant at the 0.01 level (two-tailed).

Tang.: Tangibility; Relia.: Reliability; Resp.: Responsiveness; Ass.: Assurance and Emp.: Empathy.

\section{2) Assessment of the dimensions of perceived quality} and expected quality

Overall, three dimensions of the quality offered (perceived by the students) are below the satisfaction average. Indeed, the dimension of "Responsiveness" has the lowest average $(1.89 \pm 1.01)$, while the dimensions of "Tangibility", "Assurance" and "Reliability" have relatively close values, but are insufficient for the students. In contrast, the dimension of "Empathy" is moderately satisfactory and is relatively the highest dimension (3.57士.71).

The comparative analysis between the scores obtained of the services offered and those expected by the students did reveal quality gaps, relative to the five scale dimensions.

The details of these results are summarized in the following table.
TABLE IV. VARIATION IN SCORES OF THE FIVE QUALITY DIMENSIONS AND THE GAP BETWEEN PERCEIVED AND EXPECTED QUALITY OF SERVICES IN STPSA.

\begin{tabular}{|c|c|c|c|c|}
\hline \multirow{2}{*}{ Dim. } & \multicolumn{2}{|c|}{ Quality Score } & \multirow[b]{2}{*}{ (G) } & \multirow[b]{2}{*}{ (S) } \\
\hline & $\mathbf{P}$ & $\mathbf{E}$ & & \\
\hline Tang. & $\begin{array}{l}2.31 \\
\pm .76\end{array}$ & $\begin{array}{l}2.32 \\
\pm .55\end{array}$ & -0.01 & $\begin{array}{l}\text { Near Normal } \\
\text { Satisfaction }\end{array}$ \\
\hline Relia. & $\begin{array}{l}2,48 \\
\pm .76\end{array}$ & $\begin{array}{l}3.90 \\
\pm .45\end{array}$ & -1.42 & Dissatisfaction \\
\hline Resp. & $\begin{array}{c}1.89 \\
\pm 1.01 \\
\end{array}$ & $\begin{array}{r}3.83 \\
\pm .21 \\
\end{array}$ & -1.94 & Dissatisfaction \\
\hline Ass. & $\begin{array}{l}2.24 \\
\pm .87\end{array}$ & $\begin{array}{l}3.61 \\
\pm .02\end{array}$ & -1.37 & Dissatisfaction \\
\hline Emp. & $\begin{array}{l}3.57 \\
\pm .71 \\
\end{array}$ & $\begin{array}{l}2.04 \\
\pm .48 \\
\end{array}$ & 1.53 & Satisfaction \\
\hline Global & $\begin{array}{l}2.39 \\
\pm .78\end{array}$ & $\begin{array}{l}3.14 \\
\pm .42\end{array}$ & -0.75 & Dissatisfaction \\
\hline
\end{tabular}

Thus, the most satisfactory dimension for STPSA students is "empathy". It records a positive deviation of 1.53 , and is the most determining variable in terms of TS quality. The quality gap concerning the tangibility dimension is almost null (-0.01). Students seem normally satisfied with this dimension.

The variable "Responsiveness" has the most negative gap in this evaluation (-1.94). For students, it represents the weakest link in the TS. With negative variances $(-1.42$ and -1.37 , respectively), the two variables "Reliability" and "Assurance" reinforce students' dissatisfaction with the STPSA field. In the end, our respondents clearly display an attitude of general dissatisfaction $(2.39 \pm 0.78)$ with the TS in STPSA.

\section{B. Assessment of satisfaction with TS-STPSA domains as an indicator of quality}

We first test the reliability analysis of the student's satisfaction scale toward the TS domains. Then, we present and analyze the scores of its four variables.

1) Testing the reliability of the satisfaction scale toward the TS's domains.

The scale measuring satisfaction with the TS domains is made up of 17 items grouped into four variables (Table 5): General satisfaction, Quality of training modules, Quality of teaching materials and Relevance of training methods. It has a largely satisfactory total internal consistency (0.772).

TABLE V. RELIABILITY STATISTICS OF THE SATISFACTION SCALE VARIABLES.

\begin{tabular}{|c|c|c|}
\hline TS-STPSA Domains & $\begin{array}{c}\text { Items } \\
\text { Number }\end{array}$ & $\begin{array}{c}\text { Cronbach's } \\
\text { Alpha (a) }\end{array}$ \\
\hline General Satisfaction & 2 & 0.726 \\
\hline Quality of training modules & 5 & 0.712 \\
\hline Quality of teaching materials & 7 & 0.811 \\
\hline Relevance of training methods & 3 & 0.705 \\
\hline Total & 17 & 0.772 \\
\hline
\end{tabular}


All four dimensions of our scale show largely satisfactory reliability $(\alpha)$ values, ranging from 0.7 relative to "Relevance of training methods" to 0.81 for the dimension "Quality of teaching materials."

2) Assessment of satisfaction with the TS-STPSA domains.

The results of satisfaction with the four TS domains are presented successively in frequencies and percentages in Tables 6 to 9 .

TABLE VI. STUDENTS' GENERAL SATISFACTION WITH THE TS.

\begin{tabular}{|c|c|c|c|c|}
\hline \multirow{3}{*}{\multicolumn{2}{|c|}{$\begin{array}{l}\text { General student } \\
\text { satisfaction }\end{array}$}} & \multicolumn{3}{|c|}{ Gender } \\
\hline & & \multirow{2}{*}{$\begin{array}{c}\text { F } \\
\text { (n) }\end{array}$} & \multirow{2}{*}{$\begin{array}{r}M \\
\%(n)\end{array}$} & \multirow{2}{*}{$\begin{array}{r}\text { Total } \\
\% \text { (n) }\end{array}$} \\
\hline & & & & \\
\hline \multirow{4}{*}{$\begin{array}{l}\text { 1. Quality } \\
\text { of training } \\
\text { services }\end{array}$} & $\begin{array}{c}\text { Not at all } \\
\text { satisfactory }\end{array}$ & $5.5(13)$ & $2.1(5)$ & $7.6(18)$ \\
\hline & $\begin{array}{c}\text { Little } \\
\text { satisfactory }\end{array}$ & $25.2(60)$ & $26.1(62)$ & $51.3(122)$ \\
\hline & Satisfactory & $15.5(37)$ & $19.3(46)$ & $34.9(83)$ \\
\hline & $\begin{array}{c}\text { Very } \\
\text { satisfactory }\end{array}$ & $2.9(7)$ & $3.4(8)$ & $6.3(15)$ \\
\hline \multirow{4}{*}{$\begin{array}{l}\text { 2. Quality } \\
\text { of STPSA } \\
\text { bachelor } \\
\text { or/and } \\
\text { master } \\
\text { degrees. }\end{array}$} & $\begin{array}{c}\text { Not at all } \\
\text { satisfactory }\end{array}$ & $1.7(4)$ & $3.3(8)$ & $5.0(12)$ \\
\hline & $\begin{array}{c}\text { Little } \\
\text { satisfactory }\end{array}$ & $23.8(57)$ & $23.8(57)$ & 47.7 (114) \\
\hline & Satisfactory & $20.5(49)$ & $20.5(49)$ & $41.0(98)$ \\
\hline & $\begin{array}{c}\text { Very } \\
\text { satisfactory }\end{array}$ & $2.9(7)$ & $3.3(8)$ & $6.3(15)$ \\
\hline
\end{tabular}

It can be deduced from this that the overall quality of the training services is perceived by $59 \%$ of the students as unsatisfactory (little and not at all satisfactory); and that half of the students $(52.7 \%)$ are dissatisfied with the Bachelor and/or Master training.

TABLE VII. SATISFACTION TOWARDS THE TRAINING MODULES' QUALITY

\begin{tabular}{|c|c|c|c|c|}
\hline \multicolumn{2}{|c|}{} & \multicolumn{3}{|c|}{ Gender } \\
\cline { 3 - 5 } \multicolumn{2}{|c|}{ Training modules' quality } & $\mathrm{F}$ & $\mathrm{M}$ & Total \\
\cline { 3 - 5 } & & $\%(\mathrm{n})$ & $\%(\mathrm{n})$ & $\%(\mathrm{n})$ \\
\hline \multirow{4}{*}{ 1. Theoretical } & Not at all & 0.8 & 3.8 & 4.6 \\
training modules. & interesting & $(2)$ & $(9)$ & $(11)$ \\
\cline { 2 - 5 } & Little & 14.2 & 13.0 & 27.2 \\
& interesting & $(34)$ & $(31)$ & $(65)$ \\
\cline { 2 - 5 } & Interesting & 23.8 & 23.4 & 47.3 \\
& & $(57)$ & $(56)$ & $(113)$ \\
\cline { 2 - 5 } & Very & 10.0 & 10.9 & 20.9 \\
& interesting & $(24)$ & $(26)$ & $(50)$ \\
\hline \multirow{4}{*}{ 2. Practical } & Not at all & 2.1 & 2.5 & 4.6 \\
training modules & interesting & $(5)$ & $(6)$ & $(11)$ \\
\cline { 2 - 5 } & Little & 7.1 & 10.1 & 17.2 \\
& interesting & $(17)$ & $(24)$ & $(41)$ \\
\cline { 2 - 5 } & \multirow{2}{*}{ Interesting } & 24.8 & 23.1 & 47.9 \\
& & $(59)$ & $(55)$ & $(114)$ \\
\hline
\end{tabular}

\begin{tabular}{|c|c|c|c|c|}
\hline & $\begin{array}{c}\text { Very } \\
\text { interesting }\end{array}$ & $\begin{array}{l}14.7 \\
(35) \\
\end{array}$ & $\begin{array}{l}15.5 \\
(37) \\
\end{array}$ & $\begin{array}{l}30.3 \\
(72) \\
\end{array}$ \\
\hline \multirow{4}{*}{$\begin{array}{l}\text { 3. Relationship } \\
\text { between } \\
\text { theoretical } \\
\text { courses and } \\
\text { practical } \\
\text { sessions. }\end{array}$} & $\begin{array}{c}\text { No } \\
\text { relationship }\end{array}$ & $\begin{array}{l}1.7 \\
(4)\end{array}$ & $\begin{array}{l}1.3 \\
(3)\end{array}$ & $\begin{array}{l}2.9 \\
(7)\end{array}$ \\
\hline & $\begin{array}{c}\text { Little } \\
\text { relationship }\end{array}$ & $\begin{array}{l}18.0 \\
(43)\end{array}$ & $\begin{array}{l}13.4 \\
(32)\end{array}$ & $\begin{array}{l}31.4 \\
(75)\end{array}$ \\
\hline & $\begin{array}{l}\text { Satisfactory } \\
\text { relationship }\end{array}$ & $\begin{array}{l}24.3 \\
(58) \\
\end{array}$ & $\begin{array}{l}28.5 \\
(68) \\
\end{array}$ & $\begin{array}{l}52.7 \\
(126) \\
\end{array}$ \\
\hline & $\begin{array}{c}\text { Very } \\
\text { satisfactory } \\
\text { relationship }\end{array}$ & $\begin{array}{c}5.0 \\
(12)\end{array}$ & $\begin{array}{c}7.9 \\
(19)\end{array}$ & $\begin{array}{l}13.0 \\
(31)\end{array}$ \\
\hline \multirow{4}{*}{$\begin{array}{l}\text { 4. Theoretical } \\
\text { modules and } \\
\text { preparation for } \\
\text { the practical } \\
\text { internship. }\end{array}$} & $\begin{array}{c}\text { Not at all } \\
\text { interesting }\end{array}$ & $\begin{array}{c}5.4 \\
(13) \\
\end{array}$ & $\begin{array}{c}4.6 \\
(11)\end{array}$ & $\begin{array}{l}10.9 \\
(24)\end{array}$ \\
\hline & $\begin{array}{c}\text { Little } \\
\text { interesting }\end{array}$ & $\begin{array}{l}18.4 \\
(44)\end{array}$ & $\begin{array}{l}21.3 \\
(51)\end{array}$ & $\begin{array}{l}39.3 \\
(95)\end{array}$ \\
\hline & Interesting & $\begin{array}{l}20.5 \\
(49) \\
\end{array}$ & $\begin{array}{l}18.0 \\
(43) \\
\end{array}$ & $\begin{array}{l}38.4 \\
(92) \\
\end{array}$ \\
\hline & $\begin{array}{c}\text { Very } \\
\text { interesting }\end{array}$ & $\begin{array}{c}4.6 \\
(11) \\
\end{array}$ & $\begin{array}{c}7.1 \\
(17) \\
\end{array}$ & $\begin{array}{l}11.4 \\
(28) \\
\end{array}$ \\
\hline \multirow{4}{*}{$\begin{array}{l}\text { 5. Importance of } \\
\text { a preparatory } \\
\text { module for the } \\
\text { internship. }\end{array}$} & $\begin{array}{l}\text { Not at all } \\
\text { important }\end{array}$ & $\begin{array}{l}1.7 \\
(4)\end{array}$ & $\begin{array}{l}0.4 \\
(1)\end{array}$ & $\begin{array}{l}2.1 \\
(5)\end{array}$ \\
\hline & $\begin{array}{c}\text { Little } \\
\text { important }\end{array}$ & $\begin{array}{c}9.2 \\
(22) \\
\end{array}$ & $\begin{array}{l}11.3 \\
(27) \\
\end{array}$ & $\begin{array}{l}20.5 \\
(49) \\
\end{array}$ \\
\hline & Important & $\begin{array}{l}15.9 \\
(38)\end{array}$ & $\begin{array}{l}19.2 \\
(46)\end{array}$ & $\begin{array}{l}35.1 \\
(84)\end{array}$ \\
\hline & $\begin{array}{c}\text { Very } \\
\text { important }\end{array}$ & $\begin{array}{l}22.2 \\
(53)\end{array}$ & $\begin{array}{l}20.1 \\
(48)\end{array}$ & $\begin{array}{c}42.3 \\
(101)\end{array}$ \\
\hline
\end{tabular}

Our students are more satisfied with the practical modules $(78 \%)$ than with the theoretical modules $(68 \%)$. $65.7 \%$ of the students are satisfied with the connection between the theoretical courses (conferences, presentations, etc.) and the practical courses (practical work, tutorials, situational exercises, etc.).

Concerning the internship, almost half of the students think that the theoretical modules do not sufficiently prepare them for the internship, and $77.4 \%$ think that it's important to set up a specific module that better prepares the students for the professional internship (Table 7).

TABLE VIII. SATISFACTION REGARDING THE QUALITY OF THE TS TEACHING MATERIALS.

\begin{tabular}{|c|c|c|c|c|}
\hline \multicolumn{2}{|c|}{ Dimension } & \multirow{2}{*}{\multicolumn{3}{|c|}{ Gender }} \\
\hline \multirow{3}{*}{\multicolumn{2}{|c|}{ Teaching Materials Quality }} & & & \\
\hline & & $\mathrm{F}$ & $\mathrm{M}$ & Total \\
\hline & & $\%(n)$ & $\%(\mathrm{n})$ & $\%(\mathrm{n})$ \\
\hline \multirow{4}{*}{$\begin{array}{l}\text { 1. Availability } \\
\text { of course } \\
\text { materials and } \\
\text { documents }\end{array}$} & $\begin{array}{l}\text { For no } \\
\text { module }\end{array}$ & $\begin{array}{l}3.2 \\
(5)\end{array}$ & $\begin{array}{l}10.2 \\
(16)\end{array}$ & $\begin{array}{l}13.4 \\
(21)\end{array}$ \\
\hline & $\begin{array}{c}\text { Few } \\
\text { modules }\end{array}$ & $\begin{array}{l}28.7 \\
(45)\end{array}$ & $\begin{array}{l}37.6 \\
(59)\end{array}$ & $\begin{array}{c}66.2 \\
(104)\end{array}$ \\
\hline & $\begin{array}{c}\text { Majority of } \\
\text { modules }\end{array}$ & $\begin{array}{l}9.6 \\
(15)\end{array}$ & $\begin{array}{l}7.0 \\
(11)\end{array}$ & $\begin{array}{l}16.6 \\
(26)\end{array}$ \\
\hline & All modules & $\begin{array}{l}1.9 \\
(3)\end{array}$ & $\begin{array}{l}1.9 \\
(3)\end{array}$ & $\begin{array}{l}3.8 \\
(6)\end{array}$ \\
\hline \multirow{4}{*}{$\begin{array}{l}\text { 2. Quality of } \\
\text { course } \\
\text { handouts and } \\
\text { materials. }\end{array}$} & $\begin{array}{c}\text { Not at all } \\
\text { satisfactory }\end{array}$ & $\begin{array}{l}3.8 \\
(9)\end{array}$ & $\begin{array}{c}5.9 \\
(14)\end{array}$ & $\begin{array}{l}9.7 \\
(23)\end{array}$ \\
\hline & $\begin{array}{c}\text { Little } \\
\text { satisfactory }\end{array}$ & $\begin{array}{l}15.2 \\
(36)\end{array}$ & $\begin{array}{l}17.3 \\
(41)\end{array}$ & $\begin{array}{l}32.5 \\
(77)\end{array}$ \\
\hline & Satisfactory & $\begin{array}{l}23.2 \\
(55) \\
\end{array}$ & $\begin{array}{l}23.6 \\
(56) \\
\end{array}$ & $\begin{array}{r}46.8 \\
(111) \\
\end{array}$ \\
\hline & $\begin{array}{c}\text { Very } \\
\text { satisfactory }\end{array}$ & $\begin{array}{l}7.2 \\
(17)\end{array}$ & $\begin{array}{l}3.8 \\
(9)\end{array}$ & $\begin{array}{l}11.0 \\
(26)\end{array}$ \\
\hline
\end{tabular}




\begin{tabular}{|c|c|c|c|c|}
\hline \multirow{4}{*}{$\begin{array}{l}\text { 3. The quality } \\
\text { of the } \\
\text { buildings and } \\
\text { non-sports } \\
\text { facilities }\end{array}$} & $\begin{array}{l}\text { Not at all } \\
\text { satisfactory }\end{array}$ & $\begin{array}{c}7.5 \\
(18)\end{array}$ & $\begin{array}{l}7.9 \\
(19)\end{array}$ & $\begin{array}{l}15.5 \\
(37)\end{array}$ \\
\hline & $\begin{array}{c}\text { Little } \\
\text { satisfactory }\end{array}$ & $\begin{array}{l}27.2 \\
(65)\end{array}$ & $\begin{array}{l}20.9 \\
(50)\end{array}$ & $\begin{array}{l}48.1 \\
(115)\end{array}$ \\
\hline & Satisfactory & $\begin{array}{l}13.4 \\
(32) \\
\end{array}$ & $\begin{array}{l}20.9 \\
(50) \\
\end{array}$ & $\begin{array}{l}34.3 \\
(82) \\
\end{array}$ \\
\hline & $\begin{array}{c}\text { Very } \\
\text { satisfactory }\end{array}$ & $\begin{array}{l}0.8 \\
(2)\end{array}$ & $\begin{array}{l}1.3 \\
(3)\end{array}$ & $\begin{array}{l}2.1 \\
(5)\end{array}$ \\
\hline \multirow{4}{*}{$\begin{array}{l}\text { 4. The quality } \\
\text { of the sport } \\
\text { facilities. }\end{array}$} & $\begin{array}{c}\text { Not at all } \\
\text { satisfactory }\end{array}$ & $\begin{array}{l}26.4 \\
(63)\end{array}$ & $\begin{array}{l}21.8 \\
(52)\end{array}$ & $\begin{array}{l}48.1 \\
(115)\end{array}$ \\
\hline & $\begin{array}{c}\text { Little } \\
\text { satisfactory }\end{array}$ & $\begin{array}{l}20.1 \\
(48)\end{array}$ & $\begin{array}{l}21.8 \\
(52)\end{array}$ & $\begin{array}{l}41.8 \\
(100)\end{array}$ \\
\hline & Satisfactory & $\begin{array}{l}2.1 \\
(5)\end{array}$ & $\begin{array}{c}6.7 \\
(16) \\
\end{array}$ & $\begin{array}{c}8.8 \\
(21) \\
\end{array}$ \\
\hline & $\begin{array}{c}\text { Very } \\
\text { satisfactory }\end{array}$ & $\begin{array}{l}0.4 \\
(1)\end{array}$ & $\begin{array}{l}0.8 \\
(2) \\
\end{array}$ & $\begin{array}{l}1.3 \\
(3) \\
\end{array}$ \\
\hline \multirow{4}{*}{$\begin{array}{l}\text { 5. The quality } \\
\text { and quantity } \\
\text { of teaching } \\
\text { and learning } \\
\text { materials. }\end{array}$} & $\begin{array}{c}\text { Not at all } \\
\text { satisfactory }\end{array}$ & $\begin{array}{l}15.1 \\
(36)\end{array}$ & $\begin{array}{l}13.8 \\
(33)\end{array}$ & $\begin{array}{l}28.9 \\
(69)\end{array}$ \\
\hline & $\begin{array}{c}\text { Little } \\
\text { satisfactory }\end{array}$ & $\begin{array}{l}24.7 \\
(59)\end{array}$ & $\begin{array}{l}20.5 \\
(49)\end{array}$ & $\begin{array}{c}45.2 \\
(108)\end{array}$ \\
\hline & Satisfactory & $\begin{array}{c}8.8 \\
(21) \\
\end{array}$ & $\begin{array}{l}15.1 \\
(36) \\
\end{array}$ & $\begin{array}{l}23.8 \\
(57) \\
\end{array}$ \\
\hline & $\begin{array}{c}\text { Very } \\
\text { satisfactory }\end{array}$ & $\begin{array}{l}0.4 \\
(1)\end{array}$ & $\begin{array}{l}1.7 \\
(4)\end{array}$ & $\begin{array}{l}2.1 \\
(5) \\
\end{array}$ \\
\hline \multirow{4}{*}{$\begin{array}{l}\text { 6. The time } \\
\text { load in the } \\
\text { school's } \\
\text { weekly } \\
\text { timetable. }\end{array}$} & $\begin{array}{c}\text { Not at all } \\
\text { satisfactory }\end{array}$ & $\begin{array}{l}10.5 \\
(25)\end{array}$ & $\begin{array}{l}7.9 \\
(19)\end{array}$ & $\begin{array}{l}18.4 \\
(44)\end{array}$ \\
\hline & $\begin{array}{c}\text { Little } \\
\text { satisfactory }\end{array}$ & $\begin{array}{l}25.9 \\
(62)\end{array}$ & $\begin{array}{l}28.5 \\
(68)\end{array}$ & $\begin{array}{r}54.4 \\
(130) \\
\end{array}$ \\
\hline & Satisfactory & $\begin{array}{l}11.3 \\
(27) \\
\end{array}$ & $\begin{array}{l}12.1 \\
(29) \\
\end{array}$ & $\begin{array}{l}23.4 \\
(56) \\
\end{array}$ \\
\hline & $\begin{array}{c}\text { Very } \\
\text { satisfactory }\end{array}$ & $\begin{array}{l}1.3 \\
(3) \\
\end{array}$ & $\begin{array}{l}2.5 \\
(6) \\
\end{array}$ & $\begin{array}{l}3.8 \\
(9) \\
\end{array}$ \\
\hline \multirow{4}{*}{$\begin{array}{l}\text { 7. The quality } \\
\text { of student } \\
\text { services. }\end{array}$} & $\begin{array}{c}\text { Not at all } \\
\text { satisfactory }\end{array}$ & $\begin{array}{l}21.4 \\
(51)\end{array}$ & $\begin{array}{l}18.9 \\
(45)\end{array}$ & $\begin{array}{l}40.3 \\
(96)\end{array}$ \\
\hline & $\begin{array}{c}\text { Little } \\
\text { satisfactory }\end{array}$ & $\begin{array}{l}17.2 \\
(41) \\
\end{array}$ & $\begin{array}{l}18.5 \\
(44) \\
\end{array}$ & $\begin{array}{l}35.7 \\
(85) \\
\end{array}$ \\
\hline & Satisfactory & $\begin{array}{l}10.1 \\
(24) \\
\end{array}$ & $\begin{array}{l}11.8 \\
(28) \\
\end{array}$ & $\begin{array}{l}21.8 \\
(52) \\
\end{array}$ \\
\hline & $\begin{array}{c}\text { Very } \\
\text { satisfactory }\end{array}$ & $\begin{array}{l}0,0 \\
(0)\end{array}$ & $\begin{array}{l}2.1 \\
(5)\end{array}$ & $\begin{array}{l}2.1 \\
(5)\end{array}$ \\
\hline
\end{tabular}

Regarding the assessment of the quality of the teaching materials, $79.6 \%$ of the students affirm that the handouts of the modules are little or not available to the students, and $58 \%$ think that the documents made available are acceptable and satisfactory quality (Table 8 ).

As for the global quality of the TS infrastructures, $63.6 \%$ consider that the non-sport facilities (classrooms, amphitheaters, relaxation areas, library, refreshment stand... etc.) are insufficient in quality, while $90 \%$ judge the quality of the sports facilities as little or not at all satisfactory.

Similarly, $74 \%$ of the students also thought that the teaching materials used in the courses were little or not at all satisfactory in quantity and quality.

Concerning the weekly workload, $72.8 \%$ of the students find that their timetable is little or not at all charged.
Finally, the quality of administrative services provided to students (library, student affairs, etc.) is judged by $40 \%$ of students as unsatisfactory, and only $2 \%$ of respondents find it very satisfactory.

TABLE IX. SATISFACTION WITH THE RELEVANCE OF THE TRAINING METHODS.

\begin{tabular}{|c|c|c|c|c|}
\hline \multirow{3}{*}{\multicolumn{2}{|c|}{$\begin{array}{l}\text { Relevance of the training } \\
\text { methods }\end{array}$}} & \multicolumn{3}{|c|}{ Gender } \\
\hline & & \multirow{2}{*}{$\frac{F}{\%(n)}$} & \multirow{2}{*}{$\frac{M}{\%(n)}$} & \multirow{2}{*}{$\begin{array}{l}\text { Total } \\
\%(\mathrm{n})\end{array}$} \\
\hline & & & & \\
\hline \multirow{4}{*}{$\begin{array}{l}\text { 1. The relevance } \\
\text { of training } \\
\text { methods. }\end{array}$} & $\begin{array}{c}\text { Not at all } \\
\text { relevant }\end{array}$ & $\begin{array}{l}1.7 \\
(4)\end{array}$ & $\begin{array}{c}5.4 \\
(13) \\
\end{array}$ & $\begin{array}{c}5.4 \\
(13) \\
\end{array}$ \\
\hline & $\begin{array}{l}\text { Little } \\
\text { relevant }\end{array}$ & $\begin{array}{l}21.3 \\
(51)\end{array}$ & $\begin{array}{l}36.8 \\
(88)\end{array}$ & $\begin{array}{l}36.8 \\
(88)\end{array}$ \\
\hline & Relevant & $\begin{array}{l}23.8 \\
(57) \\
\end{array}$ & $\begin{array}{l}51.5 \\
(123) \\
\end{array}$ & $\begin{array}{l}51.5 \\
(123) \\
\end{array}$ \\
\hline & $\begin{array}{c}\text { Very } \\
\text { relevant }\end{array}$ & $\begin{array}{l}2.1 \\
(5)\end{array}$ & $\begin{array}{c}6.3 \\
(15) \\
\end{array}$ & $\begin{array}{c}6.3 \\
(15) \\
\end{array}$ \\
\hline \multirow{4}{*}{$\begin{array}{l}\text { 2. Differentiated } \\
\text { pedagogy in } \\
\text { training. }\end{array}$} & Never & $\begin{array}{c}6.3 \\
(15)\end{array}$ & $\begin{array}{l}10.5 \\
(25)\end{array}$ & $\begin{array}{l}10.5 \\
(25)\end{array}$ \\
\hline & Rarely & $\begin{array}{l}21.3 \\
(51)\end{array}$ & $\begin{array}{l}43.9 \\
(105)\end{array}$ & $\begin{array}{l}43.9 \\
(105)\end{array}$ \\
\hline & Often & $\begin{array}{l}19.7 \\
(47)\end{array}$ & $\begin{array}{l}39.3 \\
(94) \\
\end{array}$ & $\begin{array}{l}39.3 \\
(94) \\
\end{array}$ \\
\hline & Always & $\begin{array}{l}1.7 \\
(4)\end{array}$ & $\begin{array}{c}6.3 \\
(15)\end{array}$ & $\begin{array}{c}6.3 \\
(15)\end{array}$ \\
\hline \multirow{4}{*}{$\begin{array}{l}\text { 3. The relevance } \\
\text { of evaluation } \\
\text { modalities. }\end{array}$} & $\begin{array}{c}\text { Not at all } \\
\text { relevant }\end{array}$ & $\begin{array}{c}4.6 \\
(11)\end{array}$ & $\begin{array}{l}10.9 \\
(26)\end{array}$ & $\begin{array}{l}10.9 \\
(26)\end{array}$ \\
\hline & $\begin{array}{c}\text { Little } \\
\text { relevant }\end{array}$ & $\begin{array}{l}16.3 \\
(39) \\
\end{array}$ & $\begin{array}{l}32.2 \\
(77)\end{array}$ & $\begin{array}{l}32.2 \\
(77) \\
\end{array}$ \\
\hline & Relevant & $\begin{array}{l}23.8 \\
(57)\end{array}$ & $\begin{array}{l}43.5 \\
(104)\end{array}$ & $\begin{array}{l}43.5 \\
(104)\end{array}$ \\
\hline & $\begin{array}{l}\text { Very } \\
\text { relevant }\end{array}$ & $\begin{array}{c}4.2 \\
(10)\end{array}$ & $\begin{array}{l}13.4 \\
(32)\end{array}$ & $\begin{array}{l}13.4 \\
(32)\end{array}$ \\
\hline
\end{tabular}

More than half of the students consider both the training methods (57.8\%) and the evaluation methods adopted by the teachers in training $(56.9 \%)$ to be relevant. While $44 \%$ claim that teachers rarely pay attention to the heterogeneity of students' levels during the teaching-training process (Table 9).

\section{Analysis of the relationship between the TS-STPSA Quality dimensions and satisfaction towards the four training domains.}

Correlation matrix analysis [21] shows 7 out of 20 positive relationships between the dimensions of perceived quality $(\mathrm{P})$ and satisfaction $(\mathrm{S})$ with the training domains (Table 10). In relation to the domains of the training device, there is a positively significant relationship $(p<0.05)$ between students' overall satisfaction and three dimensions of quality: "Tangibility", "Responsiveness" and "Empathy".

In regard to the dimensions of the quality of the training device, the " Responsiveness " dimension is positively correlated with two domains, namely " Overall satisfaction " of the students and " Relevance of training methods ". 
Also, the "Assurance" dimension separately has two positive correlations with "Quality of Training Modules" and "Relevance of Training Methods".

TABLE X. CORRELATION MATRIX BETWEEN THE DIMENSIONS OF PERCEIVED QUALITY AND THE TRAINING DOMAINS.

\begin{tabular}{|l|l|l|l|l|l|}
\hline Parameters & Tang. & Relia. & Resp. & Ass. & Emp. \\
\hline $\begin{array}{l}\text { Overall } \\
\text { student } \\
\text { satisfaction }\end{array}$ & $0.79 *$ & 0.55 & $0.62 *$ & 0.055 & $0.29 *$ \\
\hline $\begin{array}{l}\text { Quality of } \\
\text { training } \\
\text { modules }\end{array}$ & 0.23 & $0.66^{*}$ & 0.17 & $0.43^{*}$ & -0.11 \\
\hline $\begin{array}{l}\text { Quality of } \\
\text { teaching } \\
\text { materials }\end{array}$ & 0.45 & 0.31 & -0.03 & -0.24 & 0.06 \\
\hline $\begin{array}{l}\text { Relevance } \\
\text { of training } \\
\text { methods }\end{array}$ & 0.33 & 0.21 & $0.61 * *$ & $0.23 *$ & 0.18 \\
\hline
\end{tabular}

\section{Discussion}

The aim of this study is to assess the dimensions and domains of the overall quality of the training system (TS) in sciences and techniques of physical and sports activities (STPSA) in Moroccan higher education.

In this regard, 256 students, from five STPSA institutions of higher education, responded to an adapted version of the ServQual scale and a validated questionnaire of satisfaction with the TS domains. The first instrument measures, on the one hand, the quality of the services provided by the TS-STPSA, through five dimensions (Tangibility, Reliability, Responsiveness, Assurance and Empathy), and the perceived and expected quality by the students on the other hand. The second instrument assesses students' overall satisfaction with the TS domains, using four parameters (general satisfaction, quality of training modules, quality of training materials, and relevance of training methods). Internal consistency analysis of the ServQual scale, adapted to the context of STPSA in Moroccan higher education, showed that the Cronbach's Alpha value is sufficiently acceptable $(\alpha=0.758)$; and that all of its five dimensions (tangibility, reliability, responsiveness, assurance, and empathy) indicate largely satisfactory values ranging from 0.7 to 0.83 . Our measurement scale is quite faithful to its original dimensions. This indicates that each dimension is well described by the items that compose it. These values confirm the statistical reliability of the scale and its adequacy to the STPSA context in Moroccan higher education. The inter-dimensional correlation matrix also proves that all the dimensions are sufficiently correlated for us to consider that they measure the same construct. Therefore, the adapted ServQual scale is a reliable tool for assessing the quality of STPSA training systems. This result corroborates well the one concluded by Zeshan, Afridi \& Khan [22] and opposes those of Tyran, \& Ross [23] and Landrum, Prybutok, Zhang \& Peak [15].
In terms of the main results, the comparative analysis between the scores obtained, of the perceived services and those of the services expected by the students, revealed a general dissatisfaction attitude towards the TS in STPSA. This dissatisfaction is evidenced by "negative" quality gaps in three of the five scale dimensions.

Indeed, the most satisfying dimension among STPSA students is "empathy." It is therefore positioned as the greatest determinant of TS quality in STPSA. The "Responsiveness" variable has the most negative gap in this assessment (-1.94). Thus, the staff of STPSA institutions should make great efforts to improve their helpfulness competence to students, and develop their readiness ability to provide more help and guidance to students, and provide quick, prompt and timely services to them.

Also, with negative gaps of -1.42 and -1.37 respectively, the two variables "Reliability » and " Assurance " reinforce students' dissatisfaction with the STPSA program. In fact, a particularly low score (2.45) is noted for the item relating to the dimension of "reliability": " The teaching staff at my institution provide reliable information and useful knowledge without errors". This score indicates that respondents do not appear to be satisfied with the veracity, accuracy and importance of discerned information, or there may simply be a lack of understanding or insufficient communication going on.

Similarly, there was a second low score of (2.60) for the item relating to the "assurance" dimension: " The teaching staff have excellent skills in helping students". This score is indicative of dissatisfaction with support provided by the teaching staff. Students attribute this to a lack of skills among teachers. This may require training and skills development sessions for teachers, especially those newly recruited. These three negative gaps suggest the need for further improvement in the "Responsiveness," "Reliability," and "Assurance" dimensions of STPSA service quality. Finally, the quality gap concerning the "Tangibility" dimension of the TS is almost null (-0.01). The students seem normally satisfied with this dimension.

At the same time, the instrument for assessing satisfaction with the four domains of the training system has a satisfactory internal consistency (0.772). All four parameters show acceptable reliability values ranging from 0.7 to 0.81 . Our overall satisfaction questionnaire is well reliable to apply to the TS in STPSA.

In addition, the overall quality of training services is perceived by $59 \%$ of students as unsatisfactory. Half of the students $(52.7 \%)$ are dissatisfied with the training in bachelor or/and master. They think that the theoretical modules do not sufficiently prepare them for the practical internship and consider it important to set up a specific module that better prepares them for the professional internship. In contrast, they are more satisfied with the practical modules $(78 \%)$ than with the theoretical modules $(68 \%)$.

Regarding the assessment of the quality of the TS teaching materials, $79.6 \%$ of the students said that the module handouts are little or not available to the students, 
and only $58 \%$ think that the documents made available are of acceptable quality.

As for the overall quality of the TS infrastructure, $63.6 \%$ consider the non-sport facilities to be of insufficient quality, while $90 \%$ qualify the quality of the sport facilities as little or not at all satisfactory. Moreover, more than half of the students consider both the training methods (57.8\%) and the evaluation methods adopted by the teachers in training $(56.9 \%)$ to be relevant. While $44 \%$ affirm that teachers rarely take into consideration the heterogeneity of students' levels during the teaching-training process. Finally, the quality of administrative services provided to students is judged by $40 \%$ of the students as weak, and only $2 \%$ of the population surveyed find it excellent.

The correlation examination, between the dimensions of service quality and satisfaction with the TS- STPSA domains, revealed seven positively significant relationships:

- Three correlations between students' "Overall Satisfaction" and the dimensions of "Tangibility", "Responsiveness", and "Empathy".

- Two correlations linking the dimension of "Responsiveness" to the parameters of "Overall Satisfaction" and "Relevance of Training Methods".

- And two correlations between the "Assurance" dimension and "Quality of training modules" and "Relevance of training methods" domains.

It also emerges that the five dimensions (tangibility, reliability, responsiveness, assurance, and empathy) explain $45.7 \%$ of variation in overall student satisfaction.

Globally, the results of our study are almost similar to those of Brochado [24]; Shekarchizadeh, Rasli \& Hon-Tat [25] and Ladhari, \& Morales [26].

On the other hand, unlike Khan, Ahmed and Nawaz [27], who report the non-significant relationship between the "tangibility" dimension and university students' satisfaction, our study shows that there is a significant relationship between the "tangibility" dimension and students' satisfaction. The possible explanation for this inference is that students appreciate well when the institution's staff provides them with adequate didactic and pedagogical materials, and puts at their disposal a modern, attractive and good quality equipment.

At the end of our study, it is important to note that students' expectations and perceptions are subjective and rarely stable. They vary according to several variable factors (mood, emotion, stress, motivation...). Our results can only be generalized to the predefined STPSA market in Morocco. Therefore, a longitudinal study could probably bridge or reduce this limitation. Similarly, it would surely be interesting to evaluate the quality of STPSA training devices by different stakeholders of academic institutions (teachers, administrators, managers...). This view is in line with Lefranc [28], who recommends that the ServQual should be administered to employees to study the employee-customer relationship.

\section{CONCLUSION}

The study revealed mitigated results. In general, from the students' viewpoint, the quality of ST in STPSA in Morocco is unsatisfactory and leaves much to be desired. Indeed, there is a negative gap between the quality of perceived services and the quality of services expected by STPSA students. The solicited students' expectations greatly exceed their perception of the effective quality of the TS. This suggests that STPSA fields are not effectively fulfilling the students' initial expectations. There are many gaps in the quality of services delivered in STPSA training devices. These findings highlight the need for further improvement, especially in the dimensions of "Responsiveness", "Reliability" and "Assurance" of TS service quality.

Our results conclude that our STPSA training systems have some improvements to achieve. New methods and tools for management, evaluation and continuous quality improvement should be implemented.

This research represents an intellectual approach, with the main concern on providing guidelines. The produced outcomes remain referential to allow STPSA managers to improve the quality of their services. If the perceived services in our case are lower than the students' expectations, it is certainly not because our academic institutions have not made the necessary efforts or have not put in place the appropriate means. However, they must initiate in continuous improvement and pedagogical innovation approaches in order to respond qualitatively to the increasing students' expectations, to the higher education institutional requirements and to the STPSA specificities.

\section{REFERENCES}

[1] UNESCO, Global Monitoring Report on Education. "Accountability in education: keeping our commitments," UNESCO Publishing, 2018.

[2] UNESCO, Global Monitoring Report on Education. "Inclusion and Education," UNESCO Publishing, 2020.

[3] Groupe Banque Mondiale, Rapport sur le développement dans le monde, "Apprendre pour réaliser la promesse de la qualité d'éducation". Ed. Banque mondiale, 2018.

[4] OECD Report, "Insights into education quality: the OECD indicators", OECD Publishing, 2018.

[5] Conseil Supérieur de l'Éducation, de la Formation et de la Recherche Scientifique (CSEFRS), "L'enseignement supérieur au Maroc: efficacité, efficience et défis du système universitaire à accès ouvert", Rapport sectoriel, 2018.

[6] K. Schwab, “The global competitiveness report 2014-2015. Geneva: World Economic Forum. Réalités sociales, culturelles, économiques, politiques et géographiques, 2014.

[7] L. Endrizzi,"La qualité de l'enseignement : un engagement des établissements avec les étudiants ?", Dossier de veille de l'IFE, (93), 1-44, 2014.

[8] J. L-M. Tam, “Customer Satisfaction, Service Quality and Perceived Value: An Integrative Model, Journal of Marketing Management, 20: 7-8, 897-917, 2004.

[9] T. Nguyen,"Essai de mesure de la qualité de service dans le contexte d'enseignement supérieur universitaire au Viêtnam". 
Faculté de gestion d'entreprises, Institut universitaire de technologie, de poste et de télécommunication, Viêtnam, 2012.

[10] J.-M. De Ketele,"Évaluation des systèmes de formation". In A. Jorro (dir.),"Dictionnaire des concepts de la professionnalisation" (p.117-120). Louvain-la-Neuve: De Boeck Supérieur, 2014.

[11] L. Harvey, "Les évaluations de l'enseignement par les étudiants : vers une démarche abrégée". Mesure et évaluation en éducation, 39 (2), 1-37, 2016.

[12] A. Meignant, "Manager la formation. Un nouveau souffle après la réforme de 2014. L'ouvrage de référence des professionnels. Editions Liaisons, 2014.

[13] A. Parasuraman, V. Zeithaml, and L. Berry,“A conceptual model of service quality and its implications for future research". Journal of Marketing, Fall, vol 49: 41-50, 1985.

[14] A. Parasuraman, V. Zeithaml, and L. Berry, "Servqual: a multi-item scale for measuring consumer perceptions of service quality". Journal of Retailing, Vol. 64, (1), pp. 12-40, 1988.

[15] H. Landrum, V. Prybutok, X. Zhang and D. Peak, "Measuring IS System Service Quality with SERVQUAL: Users' Perceptions of Relative Importance of the Five SERVPERF Dimensions. The International Journal of an Emerging Transdiscipline, Volume 12, 2009.

[16] B. A. Al-Alak \& A. S. M. Alnaser,). "Assessing the relationship between higher education service quality dimensions and student satisfaction". Australian Journal of Basic and Applied Sciences, 6(1), 156-164, 2012.

[17] A. Parasuraman, V. Zeithaml and L. Berry,"Refinement and reassessment of the SERVQUAL scale". Journal of retailing, 67. 420-450, 1991.

[18] J.J. Cronin Jr., and S.A. Taylor,"Measuring service quality: a reexamination and extension". Journal of Marketing, Vol 56 (3), $55-69,1992$.

[19] J.C. Nunnally, "Psychometric theory", (2nd ed.). New York: McGraw-Hill, 1978.

[20] J.C. Nunnally and I.H. Bernstein, «Psychometry theory», McGrawHill, lnc., New York, 1994

[21] J.P. Benzécri, "Pratique de l'analyse des données.Tome I : Analyse des correspondances, exposé élémentaire”. Ed. Dunod, 1980.

[22] A. Zeshan, T. Afridi \& S. M. Khan, "Assessing service quality in business schools: implications for improvement. The 3rd International Conference on Assessing Quality in Higher Education, December 6-8, Lahore - Pakistan, 220-232, 2010.

[23] C. K. Tyran \& S. C. Ross, "Service Quality Expectations and Perceptions: Use of the SERVQUAL Instrument for Requirement Analysis". Issues in Information Systems, vol. 7, pp. 357-362, 2006.

[24] A. Brochado,"Comparing alternative instruments to measure service quality in higher education". Quality Assurance in Education, vol. 17(2), 174-190, 2009.

[25] A. Shekarchizadeh, A. Rasli \& H. Hon-Tat, "SERVQUAL in Malaysian universities: Perspectives of international students". Business Process Management Journal. Vo. 17, no 1: 67-81, 2011.

[26] R. Ladhari \& M. Morales, "Qualité de service perçue, valeur perçue et recommandation : une étude parmi les utilisateurs des bibliothèques publiques canadiennes", Library Management, vol. $29 \mathrm{n}^{\circ} 4 / 5$, pp. 352-366, 2008.

[27] M.M. Khan, I. Ahmed \& M.M. Nawaz, "Point de vue des étudiants sur la qualité des services dans les établissements d'enseignement supérieur: Une approche factuelle". Journal international des affaires et des sciences sociales, 2 (11), pp. 159-164, 2011

[28] E. Lefranc, "Le management de l'expérience client: au-delà des enquêtes satisfaction, la mesure de l'expérience vécue". Gestion et management. Conservatoire national des arts et métiers - CNAM, 2013. 